\title{
Sea-surface temperature and $f$-ratio explain large variability in the ratio of bacterial production to primary production in the Yellow Sea
}

\author{
Byung C. Cho*, Myung G. Park**, Jae H. Shim, Dong H. Choi \\ School of Earth and Environmental Sciences and Research Institute of Oceanography, Seoul National University, \\ Seoul 151-742, Republic of Korea
}

\begin{abstract}
To determine whether parameters related to hydrography and phytoplankton utilization of nitrogenous nutrients are responsible for the variability in ratios of euphotic zone-integrated bacterial production (BP) to primary production (PP), we measured bacterial production, primary production, new production, regenerated production and environmental variables in the euphotic zone in May 1995 and June 1996 at a frontal region in the Yellow Sea. The BP/PP ratios were highly variable with different hydrodynamic conditions, ranging from 0.03 for mixed waters to 0.40 for stratified waters. The BP/PP ratios were significantly correlated $\left(\mathrm{r}^{2}=0.64, \mathrm{p}<0.01\right)$ with water-column stability of the euphotic zone and, to a greater degree, with sea-surface temperature $\left(\mathrm{SST}_{;} \mathrm{r}^{2}=0.74, \mathrm{p}<\right.$ $0.001)$. SST was also closely correlated with water-column stability $\left(r^{2}=0.91, p<0.0001\right)$. An inverse relationship was found $\left(\mathrm{r}^{2}=0.61, \mathrm{p}<0.01\right)$ between BP/PP and $f$-ratios, indicating close association of the variability of the $\mathrm{BP} / \mathrm{PP}$ ratios with the relative utilization of nitrogen by phytoplankton. High $\mathrm{BP} / \mathrm{PP}$ values were found when the euphotic zone was stratified and phytoplankton mostly depended on ammonium for nitrogen source, and low BP/PP values were found when the euphotic zone was completely mixed and phytoplankton mostly depended on nitrate. Our results suggest that both turbulent mixing and water temperature were underlying physical forces regulating variations in BP/PP ratios in the Yellow Sea. It might be possible to predict energy pathways in the Yellow Sea and, presumably, in other marine environments by remote-sensing of SST and ocean color.
\end{abstract}

KEY WORDS: Bacterial production/primary production ratio $\cdot$ Water-column stability $\cdot$ Sea-surface temperature $\cdot f$-ratio $\cdot$ Yellow Sea

Resale or republication not permitted without written consent of the publisher

\section{INTRODUCTION}

In marine ecosystems, the roles of marine bacteria in biogeochemical cycles and foodweb energetics depend on bacterial utilization of organic matter produced by phytoplankton (Azam et al. 1983, Azam 1998, Williams 1998). Although euphotic-zone-integrated bacterial production (BP) comprises a substantial portion (on average $30 \%$ ) of primary production (PP), the ratio of $\mathrm{BP}$ to PP is highly variable, from 7 to $75 \%$ (Cole et al.

\footnotetext{
*E-mail: bccho@plaza.snu.ac.kr

${ }^{* *}$ Present address: Smithsonian Environmental Research Center, PO Box 28, Edgewater, Maryland 21037, USA
}

1988). With more data available from various marine environments, BP/PP ratios are now known to range from 0.1 to over $100 \%$. For example, Cho et al. (1994a) reported that during a spring bloom in the Yellow Sea BP comprised less than $4 \%$ of PP. Such low BP/PP ratios have frequently been reported for marine environments (e.g. Ducklow \& Kirchman 1983, Andersen 1988, McManus \& Peterson 1988). Conversely, BP/PP ratios up to $190 \%$ have also been reported in various marine environments (Kirchman \& Hoch 1988, Kiørboe et al. 1990, Ducklow \& Carlson 1992). Thus, elucidation of the factors and mechanisms controlling the BP/PP ratios is central to understanding and predicting the major energy pathways in the oceans. 
Currently, it is thought that hydrodynamic conditions are responsible for the structures of the pelagic food web (i.e. traditional grazing food chains or microbial loops: Cushing 1989, Legendre \& Le Fèvre 1989, Kiørboe 1993). The emerging paradigm is that in turbulent or mixed environments where large phytoplankton are abundant, traditional food chains dominate, whereas in strongly stratified oligotrophic environments where small phytoplankton are abundant, microbial food chains dominate (Azam et al. 1983, Hagström et al. 1988, Kiørboe et al. 1990, Legendre \& Le Fèvre 1995). Thus, the relative flux of organic matter from PP to bacteria can be expected to vary in relation to hydrography. Further, in stratified waters, most of PP is based on regenerated nitrogen (low $f$-ratio), whereas in mixed waters PP is increasingly dependent on new nitrogen (high $f$-ratio) (Kiørboe et al. 1990, Taylor \& Joint 1990). We hypothesized that information on hydrography and the $f$-ratio would provide clues to the explanation of the variability of $\mathrm{BP} / \mathrm{PP}$ ratios in marine systems. We tested our hypothesis at a tidal front region in the Yellow Sea, in which various hydrodynamic conditions (i.e. mixed, frontal and stratified waters) were represented. The goals of this study were to determine parameters which could explain the variability in BP/PP ratios and to investigate the mechanisms controlling the BP/PP ratios.

\section{MATERIALS AND METHODS}

Study area. The present study was conducted aboard the RV 'Eardo' on May 1995 and June 1996 at a tidal front region in the mid-eastern part of the Yellow Sea (Fig. 1). In May 1995 the front was at its innermost (neap tide \pm 4 d) position, whereas in June 1996 the front was at its outermost (spring tide $\pm 3 \mathrm{~d}$ ) position. Generally, in the northern part $\left(\mathrm{ca} 37^{\circ} \mathrm{N}\right)$ of the study area, the frontal zone develops in March ca $50 \mathrm{~km}$ offshore of the coast; it gradually approaches the coast until, around August, it weakens, disappearing in November when sea-surface temperature (SST) drops and strong northwest winds occur (Choi 1991). In the southern part, its position is constantly located near the coast from April to November. Stations were chosen to be representative of different hydrodynamic conditions. In May 1995, 3 stations were occupied: Stns 13, 4 and 10 seemed to represent the frontal, well-mixed, and stratified waters, respectively. However, Stn 10 still had high (ca $3 \mu \mathrm{M}$ ) nitrate concentrations at the surface (Shim et al. 1996), and was regarded as representing frontal waters (see Table 1). In June 1996, 8 stations were occupied and the approximate position of the tidal front in June 1996 is indicated in Fig. 1.
Production of phytoplankton and bacteria. Primary production was measured using ${ }^{14} \mathrm{C}$-bicarbonate according to Parsons et al. (1984). Water samples for production measurements were collected with 51 Niskin bottles mounted on a rosette sampler at 4 to 6 depths within the euphotic zone. The euphotic depth was determined by multiplying the Secchi disc depth by 2.7. To simulate in situ light conditions, seawater samples were incubated in $250 \mathrm{ml}$ polycarbonate bottles covered with perforated nickel screens (Stork Veco, Bedford, Massachusetts). Samples were inoculated in light and dark bottles with $2 \mu \mathrm{Ci} \mathrm{NaH}{ }^{14} \mathrm{CO}_{3}$ and incubated for $2 \mathrm{~h}$ in an on-deck incubator cooled with continuously flowing surface seawater. After the incubation, samples were filtered $(<100 \mathrm{~mm}$ of $\mathrm{Hg})$ onto $25 \mathrm{~mm}$ Whatman GF/F filters. The filters were fumed with concentrated $\mathrm{HCl}$ to remove inorganic ${ }^{14} \mathrm{C}$, placed in liquid scintillation vials, and mixed with $10 \mathrm{ml}$ Lumagel ${ }^{\circledR}$. Radioactivity was determined using a liquid scintillation counter (Packard Tri-Carb, Model 2550). Radioactivity in light bottles was corrected for uptake by dark bottles. During incubation, incident irradiance was measured at 10 min intervals using a LI-190SA quantum sensor and LI-1000 Data Logger (Li-Cor, Inc.). Daily PP was calculated by multiplying the hourly productivity value by the ratio of the daily incident irradiance to the incident irradiance during incubation.

Bacterial production was measured according to the method of Ducklow et al. (1992). Briefly, [ ${ }^{3} \mathrm{H}$-methyl] thymidine (sp. activity $=82$ to $92 \mathrm{Ci} \mathrm{mmol}^{-1}$; Amersham Inc.) was added to $10 \mathrm{ml}$ seawater to bring the final concentration to $10 \mathrm{nM}$. The samples were incubated for 1 to $1.5 \mathrm{~h}$ at in situ water temperature in the dark. The incorporated radioactivity was converted to produced cell numbers using an empirically derived conversion factor of $1.83 \times 10^{18}$ cells $\mathrm{mol}^{-1}$ of thymidine incorporated into DNA. Samples for measurements of bacterial abundance were fixed with $0.2 \mu \mathrm{m}$ filtered, borate-buffered formalin (final conc. of $2 \%$ ), stained with DAPI, and filtered on $0.2 \mu \mathrm{m}$ pore-size black Nuclepore filters. The filters were kept frozen at $-20^{\circ} \mathrm{C}$ until examination. Bacterial abundance was counted by epifluorescence microscopy (Porter \& Feig 1980). Bacterial carbon (BC) was calculated using biovolumes according to Simon \& Azam (1989). Biovolumes of bacteria were measured by taking microphotographs and projecting slides onto a paper screen (Moran et al. 1991). Fluorescent microspheres of known diameter (0.4 and $1.0 \mu \mathrm{m}$, Polysciences Inc., Warrington, PA, USA) were used for size calibration.

New and regenerated production. The uptake rates of nitrate (new production [NP]) and ammonium (regenerated production [RP]) were measured using the stable isotope ${ }^{15} \mathrm{~N}$ as a tracer (Dugdale \& Wilker- 
son 1986). To $250 \mathrm{ml}$ polycarbonate bottles, either $\mathrm{K}^{15} \mathrm{NO}_{3}$ or ${ }^{15} \mathrm{NH}_{4} \mathrm{Cl}$ (all 99.3 at.\%) were added to bring the final tracer additions to 1 and $0.2 \mu \mathrm{M}$, respectively. These enrichments were not always true tracer additions (i.e. $\leq 10 \%$ of ambient concentrations). In May 1995, the isotope additions led to enrichments ranging from 10 to $43 \%$ of ambient concentrations in nitrate uptake experiments and from 14 to $22 \%$ in ammonium uptake experiments. In June 1996, the isotope additions varied from $23 \%$ to saturating (12 out of 28 experiments) levels of ambient concentration in nitrate uptake experiments and from $11 \%$ to saturating (11 out of 28 experiments) levels in ammonium uptake experiments. After isotope additions, samples were incubated for $4 \mathrm{~h}$ in an on-deck incubator cooled with continuously flowing surface seawater. This incubation time was employed to minimize problems related to both the effect of isotope dilution during incubation and the effect of initial surge uptake (Dugdale \& Wilkerson 1986). After incubation, the samples were filtered ( $<100 \mathrm{~mm} \mathrm{Hg}$ ) onto pre-combusted $(4 \mathrm{~h}$ at $450^{\circ} \mathrm{C}$ ) Whatman $\mathrm{GF} / \mathrm{F}$ filters (diameter $25 \mathrm{~mm}$ ) and stored dry at $60^{\circ} \mathrm{C}$ until analysis of ${ }^{15} \mathrm{~N} /{ }^{14} \mathrm{~N}$ ratio with an Europa Roboprep-Tracermass GC-MS (Owens 1988). Particulate nitrogen-specific and absolute uptake rates were calculated according to Dugdale \& Wilkerson (1986). The effects on calculated uptake rates of adding excess ${ }^{15} \mathrm{~N}$-tracers to some samples were considered and corrected according to Eppley et al. (1977). The proportion of new production to total production (i.e. the $f$-ratio) was calculated as the ratio of nitrate uptake rate to the sum of nitrate and ammonium uptake rates (Eppley \& Peterson 1979). In our study area, urea uptake did not significantly contribute to total $\mathrm{N}$ production $(<4 \%$ : Shim et al. 1996). Thus, urea uptake was not measured, as $f$-ratios would be virtually unaffected (only <2\%). In this study, depth-integrated values of both bacteria and phytoplankton variables over the euphotic zone are presented unless otherwise stated.

Since samples for measurements of primary production and ${ }^{15} \mathrm{~N}$ uptake were incubated in an on-deck incubator cooled with surface seawater, temperature differences between surface and sampled depths might influence some samples, particularly from the deeper parts of stratified waters. Assuming a $Q_{10}$ of 2.3 for photosynthesis, growth, and ${ }^{15} \mathrm{~N}$ uptake (Eppley 1972, Raven \& Geider 1988), our production values were corrected for the effect of the temperature difference according to the equation $\log Q_{10}=10 /\left(t_{1}-t_{2}\right) \times \log \left(k_{1} / k_{2}\right)$, where $t_{1}=$ higher temperature $\left({ }^{\circ} \mathrm{C}\right), t_{2}=$ lower temperature $\left({ }^{\circ} \mathrm{C}\right), k_{1}=$ production rate at the higher temperature, and $k_{2}=$ production rate at the lower temperature. Robinson \& Williams (1993) showed that most $Q_{10}$ values reported for photosynthesis are within the range of 2 to 3 . The $Q_{10}$ value used for $\mathrm{N}$ uptake here was also within the range (1.4 to 3.2) reported by previous studies (Glibert et al. 1982, Paasche \& Kristiansen 1982, Smith \& Harrison 1991). When corrected for temperature, $\mathrm{PP}, \mathrm{NP}$, and RP decreased by up to 12,18 , and

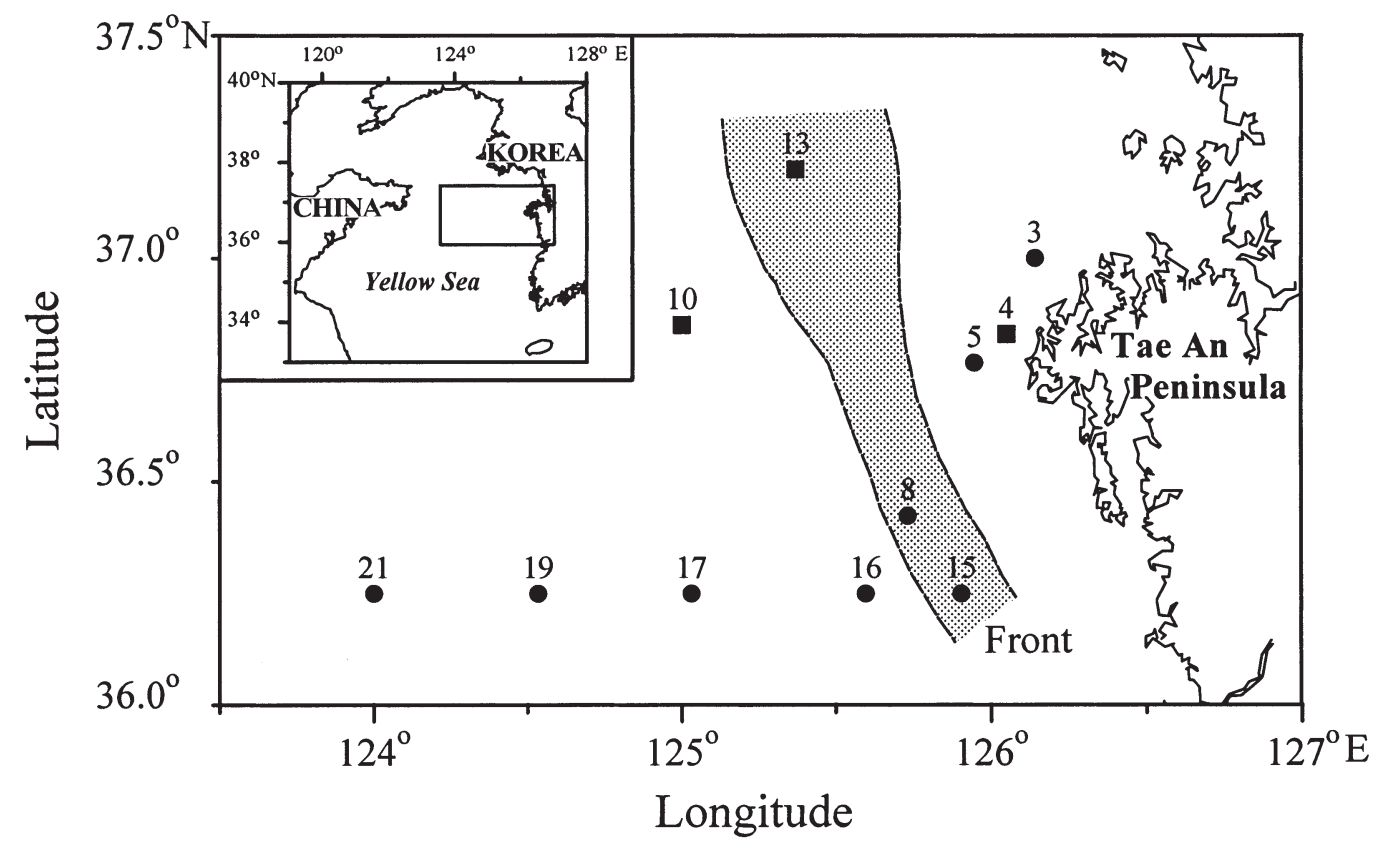

Fig. 1. Study area and sampling stations. Stations were sampled during May 1995 (ロ) and June $1996(\bullet)$. Shaded area indicates approximate position of tidal front zone in June 1996 
$19 \%$, respectively. The effects of temperature were small because most samples collected in the euphotic zone were from within the mixed layer in stratified waters, and samples collected near the euphotic depth had small production values.

Environmental variables and statistical analyses. Water temperature and salinity were measured with a CTD system (SBE-25 or SBE-911) mounted on a rosette sampler. For measurements of nutrients, seawater samples were filtered through pre-combusted Whatman GF/F filters, frozen at $-20^{\circ} \mathrm{C}$, and brought to the laboratory. Ammonium concentration was determined manually by the method of Grasshoff et al. (1983). Nitrate concentration was determined with a Bran + Luebbe Autoanalyzer (Model TRAACS 2000) by the method of Parsons et al. (1984). Concentrations of chlorophyll a (chl a) were measured spectrophotometrically according to Parsons et al. (1984). The stability index of the euphotic zone was calculated by dividing the density (sigma- $t$ ) difference between the surface and the bottom of the euphotic zone by the euphotic depth. Statistical analyses including regression analysis and non-parametric tests were done using SPSS for Windows (Version 8.0: SPSS Inc. 1997).

\section{RESULTS}

\section{Hydrography and nitrate and ammonium concentrations}

The euphotic depth in the present study ranged from 8 to 10,15 to 20 , and 15 to $32 \mathrm{~m}$ in mixed, stratified, and frontal waters, respectively (Table 1 ). Water tempera- ture within the euphotic zone varied greatly in time and space, ranging from $7.1^{\circ} \mathrm{C}$ near the bottom of the euphotic zone at Stn 10 in May 1995 to $20.9^{\circ} \mathrm{C}$ at the surface at Stn 17 in June 1996, whereas salinity within the euphotic zone showed small variations (less than 1.3 psu) in May 1995 and June 1996 (Table 1). Thus, water temperature was mainly responsible for the differences in water densities in the study area. The difference in water temperature between the surface and the bottom of the euphotic zone was less than $0.1^{\circ} \mathrm{C}$ in well-mixed waters, and reached up to 3.6 and $10.0^{\circ} \mathrm{C}$ in frontal and stratified waters, respectively. As expected, the stability index of the euphotic zone was lowest $(<0.001)$ at mixed stations. A much higher degree of stability within the euphotic zone was found at the frontal and stratified stations, ranging from 0.013 (at Stn 13) to 0.055 (at Stn 8), and from 0.078 (at Stn 16) to 0.120 (at Stn 17), respectively (Table 1).

Nitrate concentrations within the euphotic zone varied by 3 orders of magnitude, with maximum and minimum values of 10.17 (near the surface at mixed Stn 4 in May 1995) and $0.07 \mu \mathrm{M}$ (at the surface at stratified Stn 19 in June 1996), respectively (data not shown). Depth-integrated nitrate concentration over the euphotic zone ranged from 3.8 (at stratified Stn 16 in June 1996) to 111.2 mg-at. $\mathrm{N} \mathrm{m}^{-2}$ (at Stn 10 in May 1995; Table 1). Ammonium concentrations within the euphotic zone ranged from 0.1 (near the surface at Stn 5 in June 1996) to $1.91 \mu \mathrm{M}$ (near the surface at Stn 16 in June 1996) (data not shown). Depth-integrated ammonium concentration over the euphotic zone ranged from 1.0 (at Stn 5 in June 1996) to $38.3 \mathrm{mg}$-at. $\mathrm{N} \mathrm{m}^{-2}$ (at Stn 10 in May 1995; Table 1). Depth-integrated nitrate concentrations were negatively correlated with SST $\left(\mathrm{r}^{2}\right.$

Table 1. Summary of environmental variables (values in parentheses represent water temperature and salinity at the bottom of the euphotic zone) and bacterial and phytoplankton variables during this study. BC, chl $a$, NP, RP: bacterial carbon, chlorophyll $a$, new production, and regenerated production, respectively

\begin{tabular}{|c|c|c|c|c|c|c|c|c|c|c|c|c|}
\hline $\begin{array}{l}\text { Water } \\
\text { type }\end{array}$ & Date & Stn & $\begin{array}{l}\text { Euphotic } \\
\text { depth } \\
\text { (m) }\end{array}$ & $\begin{array}{c}\text { Surface } \\
\text { temp. } \\
\left({ }^{\circ} \mathrm{C}\right)\end{array}$ & $\begin{array}{l}\text { Surface } \\
\text { salinity } \\
\text { (psu) }\end{array}$ & $\begin{array}{l}\text { Stability } \\
\text { index }\end{array}$ & $\begin{array}{l}\sum\left[\mathrm{NO}_{3}\right] \\
(\mathrm{mg}-\mathrm{at} . \\
\mathrm{N} \mathrm{m}^{-2} \text { ) }\end{array}$ & $\begin{array}{c}\sum\left[\mathrm{NH}_{4}\right] \\
(\mathrm{mg}-\mathrm{at} . \\
\mathrm{N} \mathrm{m}^{-2} \text { ) }\end{array}$ & $\begin{array}{c}\sum \mathrm{BC} \\
\left(\mathrm{mg} \mathrm{C}^{-2}\right) \\
\left.\mathrm{m}^{-2}\right)\end{array}$ & $\begin{array}{c}\sum \mathrm{chl} a \\
(\mathrm{mg} \\
\left.\mathrm{m}^{-2}\right)\end{array}$ & $\begin{array}{c}\mathrm{NP} \\
(\mathrm{mg} \mathrm{N} \\
\left.\mathrm{m}^{-2} \mathrm{~d}^{-1}\right)\end{array}$ & $\begin{array}{c}\mathrm{RP} \\
(\mathrm{mg} \mathrm{N} \\
\left.\mathrm{m}^{-2} \mathrm{~d}^{-1}\right)\end{array}$ \\
\hline \multirow[t]{3}{*}{ Mixed } & May 1995 & 4 & 8 & $9.0(8.9)$ & $32.1(32.0)$ & 0.000 & 58.8 & 10.5 & 235.2 & 46.2 & 27.7 & 71.0 \\
\hline & Jun 1996 & 3 & 10 & $12.1(12.1)$ & $31.7(31.7)$ & 0.001 & 38.3 & 7.8 & 261.1 & 27.9 & 0.8 & 26.9 \\
\hline & & 5 & 10 & $11.8(11.8)$ & $31.8(31.8)$ & 0.000 & 9.5 & 1.0 & 219.5 & 45.0 & 2.8 & 5.1 \\
\hline \multirow[t]{4}{*}{ Frontal } & May 1995 & 10 & 32 & $10.5(7.1)$ & $32.4(32.5)$ & 0.018 & 111.2 & 38.3 & 652.0 & 50.6 & 155.7 & 242.9 \\
\hline & & 13 & 16 & $10.4(8.8)$ & $32.1(32.0)$ & 0.013 & 72.1 & 19.5 & 1077.7 & 107.4 & 139.8 & 216.7 \\
\hline & Jun 1996 & 15 & 15 & $14.0(13.1)$ & $31.9(32.0)$ & 0.018 & 20.1 & 8.7 & 198.0 & 13.2 & 2.1 & 11.3 \\
\hline & & 8 & 15 & $16.5(12.9)$ & $31.9(32.0)$ & 0.055 & 32.9 & 1.5 & 186.9 & 10.0 & 16.7 & 10.5 \\
\hline \multirow[t]{4}{*}{ Stratified } & Jun 1996 & 16 & 15 & $18.9(13.7)$ & $31.9(32.1)$ & 0.078 & 3.8 & 15.3 & 223.0 & 8.1 & 0.4 & 40.9 \\
\hline & & 17 & 15 & $20.9(12.6)$ & $32.5(32.3)$ & 0.120 & 27.9 & 13.1 & 566.4 & 18.1 & 4.2 & 49.9 \\
\hline & & 19 & 20 & $20.3(10.3)$ & $32.8(32.5)$ & 0.098 & 15.2 & 9.5 & 463.4 & 17.3 & 4.7 & 29.4 \\
\hline & & 21 & 20 & $20.3(13.0)$ & $32.9(33.0)$ & 0.085 & 15.7 & 21.9 & 351.9 & 11.5 & 0.1 & 46.6 \\
\hline
\end{tabular}


$=0.42, p=0.03)$ but not with the stability index $(p>0.1$; data not shown).

\section{Production of phytoplankton and bacteria, chl $a$ and bacterial carbon}

BP was significantly correlated with $\mathrm{PP}\left(\mathrm{r}^{2}=0.56, \mathrm{p}=\right.$ 0.008; Fig. 2A). PP varied 47 -fold from 66 (at stratified Stn 16) to $3148 \mathrm{mg} \mathrm{C} \mathrm{m}^{-2} \mathrm{~d}^{-1}$ (at frontal Stn 13). Primary production per unit volume decreased with increasing water temperature (Fig. 2B), and PP showed a similar trend with SST (inset in Fig. 2B). Bacterial production was also variable, ranging from 19 (at well-mixed Stn 3) to $277 \mathrm{mg} \mathrm{C} \mathrm{m}^{-2} \mathrm{~d}^{-1}$ (at frontal Stn 13). BP per unit volume and BP in this study did not significantly increase with increasing water temperature (Fig. 2C). The BP/PP ratios varied greatly with different hydrodynamic conditions, ranging from 0.03 (at well-mixed Stn 4) to 0.40 (at stratified Stn 21) (see Fig. 3A).

Depth-integrated bacterial carbon (and abundance; data not shown) over the euphotic zone did not differ ( $\mathrm{p}>0.05$ ) between mixed (219.5 to $261.1 \mathrm{mg} \mathrm{C} \mathrm{m}^{-2}$ ), frontal (186.9 to $198.0 \mathrm{mg} \mathrm{C} \mathrm{m}^{-2}$ ) and stratified (223.0 to $566.4 \mathrm{mg} \mathrm{C} \mathrm{m}^{-2}$ ) waters in June 1996. Depth-integrated chl a did not significantly differ among mixed, stratified and frontal waters in June 1996 ( $p=0.152$, Kruskal-Wallis test).

\section{New and regenerated production and $f$-ratio}

NP integrated over the euphotic zone ranged from 0.1 (at stratified Stn 21) to $155.7 \mathrm{mg} \mathrm{N} \mathrm{m}^{-2} \mathrm{~d}^{-1}$ (at frontal Stn 10; Table 1). RP integrated over the euphotic zone ranged from 5.1 (at well-mixed Stn 5) to $242.9 \mathrm{mg} \mathrm{N} \mathrm{m}^{-2}$ $\mathrm{d}^{-1}$ (at frontal Stn 10; Table 1). The $f$-ratio, calculated with NP and RP integrated over the euphotic zone, ranged from 0.002 (at stratified Stn 21) to 0.614 (at frontal Stn 8$)$. The $f$-ratio did not significantly ( $p>0.05)$ correlate with SST or the stability index (data not shown).

\section{Relationships between $\mathrm{BP} / \mathrm{PP}$ ratios, environmental variables and $f$-ratios}

The BP/PP ratios showed a statistically significant $\left(r^{2}=0.64, p=0.003\right)$ correlation with water-column stability (Fig. 3A). Water-column stability of the euphotic zone was strongly correlated with $\mathrm{SST}\left(\mathrm{r}^{2}=0.91, \mathrm{p}<\right.$ 0.0001; Fig. 3B). Thus, the distribution of SST across the frontal region in the present study was well explained by water-column stability. SST was lower in vertically well-mixed waters than in stratified waters, reflecting relatively strong turbulent mixing in mixed
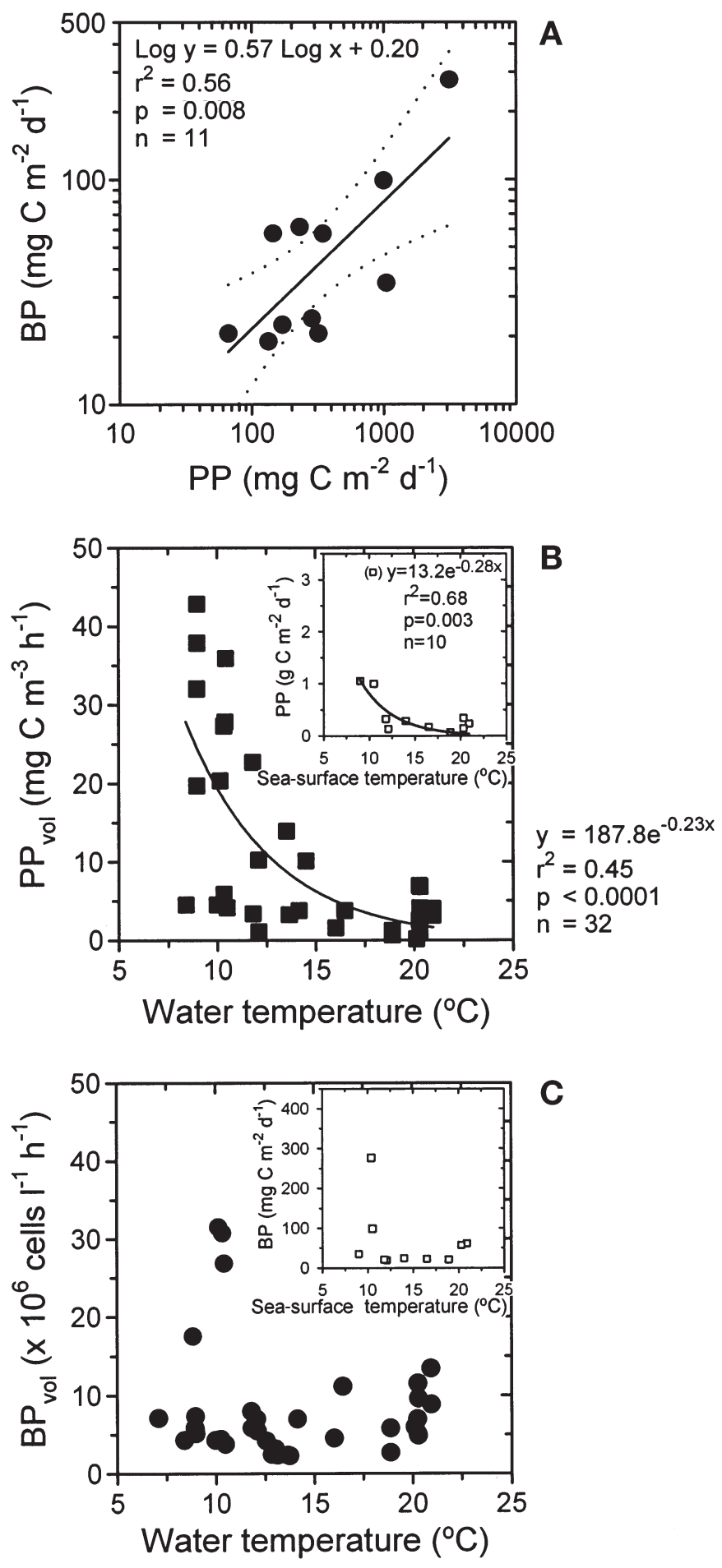

Fig. 2. Scatterplots of (A) depth-integrated bacterial production (BP) vs depth-integrated primary production (PP) of the euphotic zone; $(\mathrm{B})$ primary production per unit volume $\left(\mathrm{PP}_{\mathrm{vol}}\right)$ vs water temperature; and $(\mathrm{C})$ bacterial production per unit volume $\left(\mathrm{BP}_{\mathrm{vol}}\right)$ vs water temperature during this study. Insets in B and C: PP and BP vs sea-surface temperature, respectively. Solid and dotted lines: regression line and 95\% confidence intervals, respectively. Data point in parentheses (B inset) was not included in regression analysis 

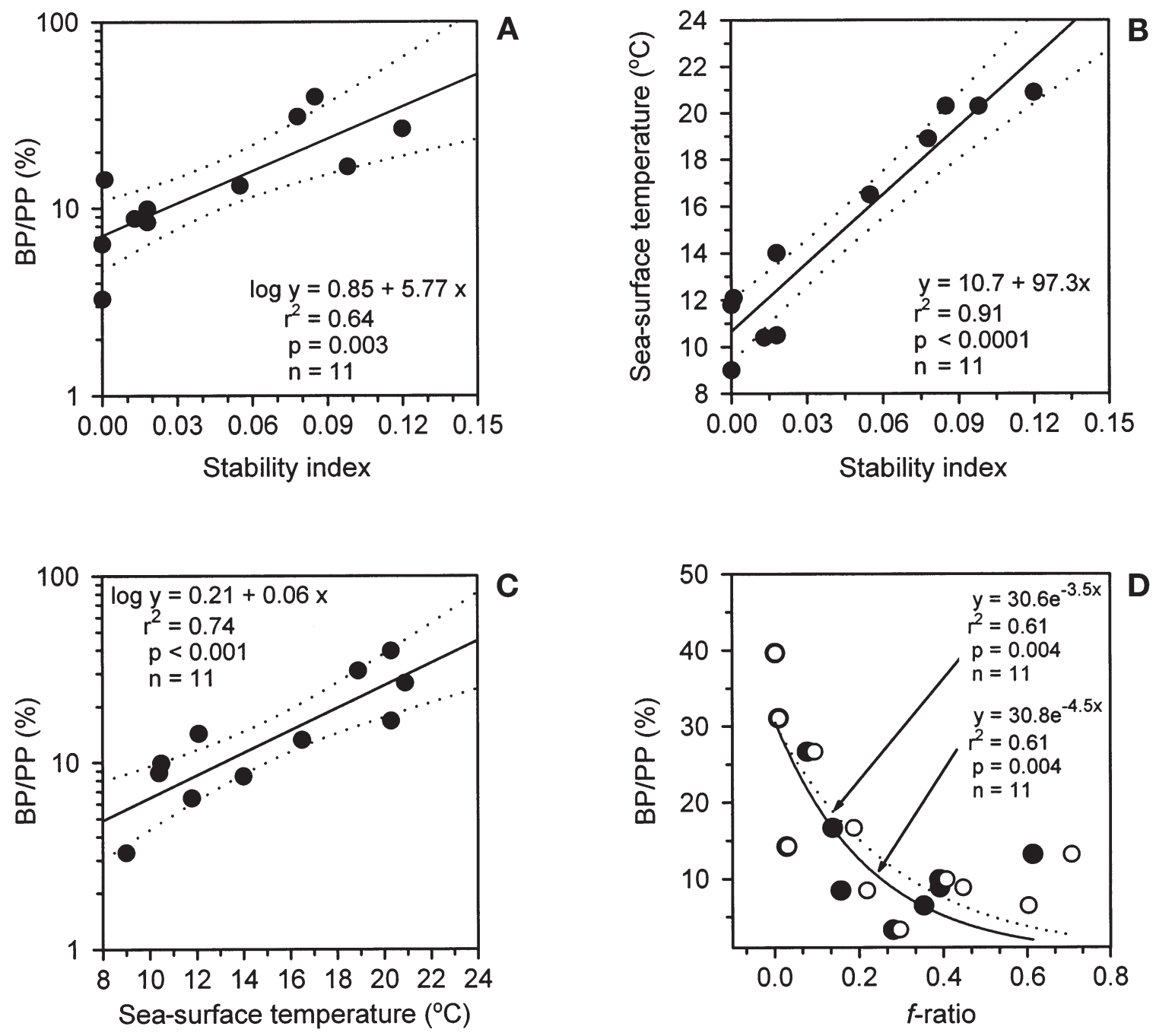

Fig. 3. Relationships between (A) ratios of depth-integrated bacterial production (BP) to primary production (PP) of the euphotic zone and stability index of the euphotic zone; (B) sea-surface temperature (SST) and stability index; (C) BP/PP ratios and SST; and (D) BP/PP ratios and $f$-ratio; data not corrected $\left(\mathbf{O}\right.$, solid line), and corrected $\left(\mathbf{O}\right.$, dotted line) for bacterial uptake of $\mathrm{NH}_{4}-\mathrm{N}$. $(\mathrm{A}-\mathrm{C})$ Solid and dotted lines: regression line and $95 \%$ confidence intervals, respectively

waters and restricted turbulent mixing in stratified waters. Interestingly, SST, a proxy of water-column stability, better correlated with BP/PP ratios $\left(\mathrm{r}^{2}=0.74\right.$, $\mathrm{p}<0.001$; Fig. 3C) than did water-column stability. Further, a significant inverse correlation between $\mathrm{BP} / \mathrm{PP}$ and $f$-ratios was found $\left(\mathrm{r}^{2}=0.61, \mathrm{p}=0.004\right.$; Fig. 3D). BP/PP ratios were not significantly correlated with depth-integrated nitrate concentrations over the euphotic zone $\left(\mathrm{r}^{2}=0.25, \mathrm{p}=0.11\right.$; data not shown).

\section{DISCUSSION}

A significant finding of this study was that variations in $\mathrm{BP} / \mathrm{PP}$ ratios in the Yellow Sea were largely ex- plained by SST (Fig. 3C). Our values of BP and PP and the relationship between BP and PP are similar to results found for coastal and open-ocean waters (Cole et al. 1988, Kirchman et al. 1993). Also, the observed range (0.03 to 0.40 ) of BP/PP ratios during this study was within the range of 0.001 to 1.90 reported for coastal and open-ocean waters (Cole et al. 1988, Ducklow \& Carlson 1992, Kirchman et al. 1993, Cho et al. 1994a). Considering the factors and complexities of the processes regulating PP and BP in the sea (Eppley 1986, Azam \& Smith 1991, Falkowski \& Woodhead 1992) and the large variations in PP and BP (48-fold and 10-fold variations, respectively) in the Yellow Sea, it is intriguing that a single variable, SST, explained the major variations of BP/PP ratios found across the frontal region. 
In the present study, water-column stability of the euphotic zone was primarily caused by the temperature difference between the surface and the bottom of the euphotic zone (Table 1). Observations of higher SST at more stratified stations and lower SST in more mixed waters (Fig. 3B) thus indicate that lower SST was due to relatively strong turbulent mixing of cold bottom water in mixed waters, while higher SST was due to restricted turbulent mixing in stratified waters. Therefore, SST in this study implied mixing and roughly corresponded to the water-temperature conditions in the euphotic zone. In fact, the averaged temperature for the euphotic zone correlated significantly with SST $\left(\mathrm{r}^{2}=0.96, \mathrm{p}<0.001, \mathrm{n}=11\right.$; data not shown). The observed distributions of BP/PP ratios in the study area could thus have resulted from the combined effects of turbulent mixing and water temperature on food-web dynamics. The fact that SST accounted for $10 \%$ more of the variation in BP/PP ratios than watercolumn stability is consistent with this idea.

Until now, combined effects of turbulent mixing and water temperature on microbial food webs have not been studied. However, comparisons of our field data with studies on effects of physical factors suggest that both mixing and temperature would be responsible for the observed distributions of BP and PP across the frontal region: Peters et al. (1998) pointed out that in turbulent waters bacterial abundance and production are higher than in stagnant waters, but bacterial growth rates (i.e. bacterial production/bacterial abundance) are similar in the 2 types of waters when bacteria co-exist with other food-web microbes. Their experiments had been conducted at the same temperatures for both stagnant and turbulent conditions. Our data showed no significant $(\mathrm{p}>0.05)$ differences in bacterial growth among well-mixed, frontal and stratified waters, consistent with the results of Peters et al. (1998). However, when considering all data, and June 1996 data only, no differences were found in bacterial carbon, abundance and production between the various hydrographic conditions ( $p>0.05)$. Because SST was lower at well-mixed stations, we might expect that lower temperature compensated for the stimulating effect of turbulence on BP. Likewise, a temperature effect on volumetric and depth-integrated BP was not clearly evident in this study (Fig. 2C). It seems that combined effects of turbulence and temperature were responsible for the disparities. In addition, the negative relationship of water temperature with volumetric and depth-integrated PP (Fig. 2B) also suggests combined effects of temperature and mixing, with mixing dominating over temperature in regulating PP in the study area. Since temperature has a positive effect on phytoplankton production (Li 1985), the negative effect observed in our study can most likely be explained by the positive rela- tionship of PP with nitrate $\left(\mathrm{r}^{2}=0.54, \mathrm{p}=0.01\right.$; data not shown) which showed higher concentrations when water temperature was low and vice versa. Thus, the negative relationship might be caused by the water-column stability, which restricted transport of nutrient (i.e. nitrate)-rich bottom water to the surface water and subsequently limited phytoplankton growth. Consistently, for 9 out of 11 data, phytoplankton growth rates correlated positively $\left(\mathrm{r}^{2}=0.69, \mathrm{p}=0.006\right)$ with $f$-ratios in the Yellow Sea (data not shown). Overall, it seems that turbulent mixing and water temperature are the driving forces of material flows through the microbial food web and lead to the observed variations in BP/PP ratios in the study area.

The observations of low BP/PP ratios in mixed waters and high ratios in stratified waters seem to be consistent with the present knowledge of export production and might be explained in part by the relative use of ammonium to nitrate by phytoplankton, as illustrated by the inverse relationship between BP/PP and $f$-ratios in our study. High $f$-ratios are usually associated with high export production in mixed waters (Legendre \& Gosselin 1989, Legendre \& Le Fèvre 1989, 1995). Hence, under these conditions less organic matter remains in the surface mixed layer which can be consumed by bacteria, thus reducing the BP/PP ratio. Therefore, observations of low BP/PP ratios in mixed waters and high ratios in stratified waters are intuitively consistent with the present concept of export production. To interpret properly the relationship between $f$-ratios and BP/PP ratios, it would be necessary to consider the potential contribution of bacterial ammonium-N uptake to RP. As Whatman GF/F filters (nominal pore size $0.7 \mu \mathrm{m}$ ) were used to collect particulate material after incubation with ${ }^{15} \mathrm{~N}$-labelled ammonium in this study, marine bacteria might contribute to RP. Assuming that bacteria used only ammonium-N as $\mathrm{N}$ source, that the bacterial $\mathrm{C} / \mathrm{N}$ ratio is 4.2 (Nagata 1986), and that the retention efficiency of natural marine bacteria by GF/F filters is ca $2 / 3$, we estimated that bacterial $\mathrm{N}$ requirements corresponded to 6 to $33 \%$ of the measured RP, with an exceptionally high value of $64 \%$ in 1 sample (at well-mixed Stn 5; data not shown). After correcting the portion of bacterial contribution to $\mathrm{RP}$, we obtained a similar relationship between BP/PP and the corrected $f$-ratio $\left(\mathrm{r}^{2}=0.61\right.$, $\mathrm{p}=0.004$; Fig. 3D). Thus, the observations of low BP/PP ratios in mixed waters and high ratios in stratified waters might be explained in part by the preferential use of ammonium over nitrate by phytoplankton.

The use of different $\mathrm{N}$ sources by phytoplankton is known to affect the release of dissolved organic nitrogen (DON) and its composition (Bronk \& Glibert 1991), which might result in limitation of growth substrates in bacteria. In fact, substrate-limitation in bacterial growth 
was suggested by a significant correlation $\left(\mathrm{r}^{2}=0.77\right.$, $\mathrm{p}<0.001$; Fig. 4) between bacterial and phytoplankton growth in the Yellow Sea. Growing evidence shows that large phytoplankton use primarily $\mathrm{NO}_{3}{ }^{-}$as a $\mathrm{N}$ source and small phytoplankton primarily $\mathrm{NH}_{4}{ }^{+}$ (Probyn 1985, Koike et al. 1986, Probyn et al. 1990). In the frontal region of the Yellow Sea, it was shown that nanoplankton $(<20 \mu \mathrm{m})$ comprised a much larger fraction of total chl $a$ and PP in June in stratified waters than in mixed and frontal waters (Choi 1991). Thus, it would be expected that in stratified waters of the Yellow Sea, phytoplankton use more $\mathrm{NH}_{4}{ }^{+}$than $\mathrm{NO}_{3}^{-}$ compared to mixed and frontal waters. During the decline of the spring bloom in the Chesapeake Bay, Bronk \& Glibert (1991) found that total DON release rates resulting from $\mathrm{NH}_{4}{ }^{+}$uptake were several-fold higher than those resulting from $\mathrm{NO}_{3}{ }^{-}$uptake and that the release of low-molecular weight DON upon $\mathrm{NH}_{4}{ }^{+}$ uptake comprised 21 to $78 \%$ of the total DON released, whereas both low molecular weight and total DON releases upon $\mathrm{NO}_{3}{ }^{-}$uptake were low. However, phytoplankton exudates alone would not be sufficient to explain the occurrence of high $\mathrm{BP} / \mathrm{PP}$ ratios $(>7 \%)$ (Conan et al. 1999), as exudates comprise on average only $13 \%$ of the total production in marine environments (Baines \& Pace 1991). Alternative mechanisms of DOM (dissolved organic matter) production must be more active in stratified waters in order to fulfil the observed high BP/PP ratios, i.e. autocatalytic cell lysis of phytoplankton (Berges \& Falkowski 1998), particle solubilization (Smith et al. 1992, 1995), or viral lysis (Agustí et al. 1998, Fuhrman 1999). Consistently, recent field studies suggest that high lysis rates of phytoplankton may be a common feature of summer stratified waters (Agustí et al. 1998). In short, physical conditions (i.e. mixing and temperature) represented well by SST in the Yellow Sea would control the supply of $\mathrm{N}$ nutrients to the phytoplankton. Phytoplankton adapted to a specific hydrographic condition would determine the quantity and quality of DOM released, thereby controlling bacterial utilization of DOM and production. Further, the significance and modes of food-web interactions producing DOM might differ in various hydrographic conditions. Consequently, variations of BP/PP were apparently related to SST.

Considering the variations in bacterial growth efficiencies in some areas, we might expect that bacterial growth efficiencies would vary 2- to 3-fold across less productive to highly productive waters in a given study area, with lower efficiency in less productive waters and vice versa (Griffith et al. 1990, Biddanda et al. 1994, del Giorgio et al. 1997). In the northern Gulf of Mexico, Biddanda et al. (1994) reported that bacterial growth efficiencies ranged from $26 \%$ in less productive slope water to $50 \%$ in highly productive shelf wa-

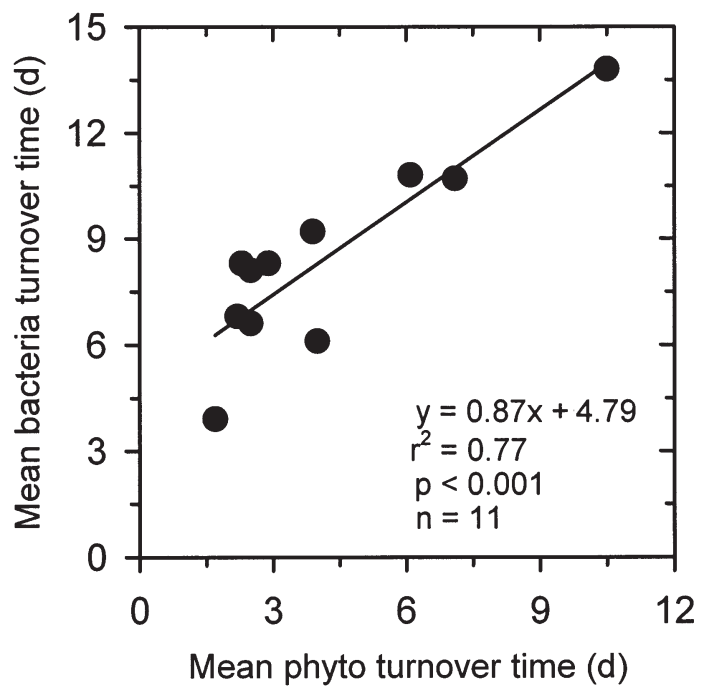

Fig. 4. Scatterplot of turnover time of phytoplankton vs that of bacteria calculated for the euphotic depth. Phytoplankton carbon was calculated using a C:chl a ratio of 50

ter. On the Georgia shelf, Griffith et al. (1990) found that bacterial growth efficiencies decreased with increasing distance from shore, ranging from $2 \%$ in shelf waters to $6 \%$ in nearshore water. Thus, a higher efficiency of bacteria in waters with higher PP (i.e. lower SST, see Fig. 2B) would support our conclusion of a relatively higher flux of organic matter to bacteria in stratified than in mixed waters. Therefore, our results are consistent with the earlier notions that traditional food chains dominate in turbulent or mixed waters, whereas microbial food chains dominate in strongly stratified waters (Azam et al. 1983, Hagström et al. 1988, Kiørboe et al. 1990, Legendre \& Le Fèvre 1995).

If physical forces such as turbulent mixing and temperature can be considered as influential regulating factors in plankton ecology (White et al. 1991, Kirchman et al. 1995, Peters et al. 1998, Petersen et al. 1998), we would expect to find trends similar to the BP/PP versus SST relationship observed in the Yellow Sea in other regions. Temporally independent (i.e. August 1987 and 1991) data from the same area of the Yellow Sea (Cho et al. 1994b) closely fit the relationship found in our study (Fig. 5). We also found a positive relationship (but with a different slope and $y$-axis intercept) between BP/PP and SST in the open sea of the East Sea (B.C.C. unpubl. data) based on data covering winter to summer of 3 succeeding years. These results suggest that a positive relationship between SST (or the stability index) and BP/PP ratios could exist in other temperate regions.

To date, the causes of variability in the BP/PP ratios in the field remain to be explained (Kirchman et al. 


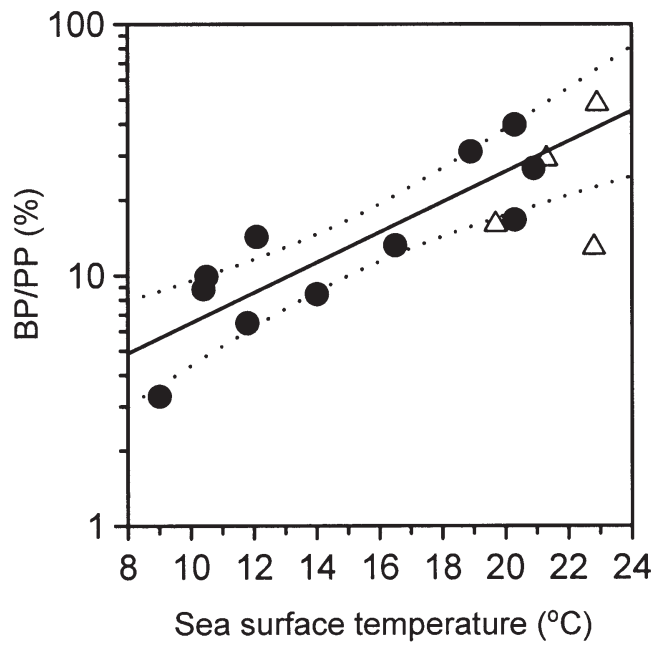

Fig. 5. Temporally independent data (Cho et al. 1994b, $\Delta$ ) from the same area of the Yellow Sea plotted together with the relationship from this study $(\bullet)$. Solid and dotted lines: regression line and $95 \%$ confidence intervals, respectively

1995, Azam 1998). Very recently, phytoplankton efficiency ( $\mathrm{PE}$, defined as the ratio between depth-integrated PP and depth-integrated chlorophyll, in units of $\mathrm{mg} \mathrm{C} \mathrm{mg}{ }^{-1} \mathrm{chl} \mathrm{a} \mathrm{h}^{-1}$ ) is reported to be well correlated with BP/PP ratios in the Mediterranean Sea (Conan et al. 1999). In both the Yellow and East Seas, however, correlation of $\mathrm{PE}$ with $\mathrm{BP} / \mathrm{PP}$ ratios was not significant $(p>0.3)$, probably reflecting regional differences in such relationships. Of $9 \mathrm{BP} / \mathrm{PP}$ ratios, 3 were greater than 0.25 (i.e. 0.26 to 0.40 ) when PE was higher than 1. Since PE is itself affected by many factors including light, nutrient conditions, trophic conditions of waters, phytoplankton cell size and species, and water-column stability (Conan et al. 1999), SST might constitute a direct variable for monitoring the variations in BP/PP ratios in the marine environment. Since SST and ocean color can be remotely sensed (Prabhakara et al. 1974, Platt \& Sathyendranath 1988, Antoine et al. 1996), precise prediction of BP and energy pathways in some oceanic regions could be possible. Finally, SST is related to various biological oceanographic processes influenced by climatic changes (Sanford 1999, Smith \& Kaufmann 1999). Thus, the sensitive responses of $\mathrm{BP} / \mathrm{PP}$ ratios to SST might also be a useful framework for understanding effects of climatic changes on marine microbiological processes. As global warming proceeds, BP/PP ratios would be expected to increase in the ocean, and thereby the energy flow to higher trophic levels and to the deep-sea might be expected to decrease. Our results would provide a biological explanation for recent observations (Smith \& Kaufmann 1999), whereby a deficit supply of particulate organic carbon to the deep-sea floor was attributed to sea-surface warming.

In conclusion, the variability in $\mathrm{BP} / \mathrm{PP}$ ratios in the Yellow Sea was related to SST and water-column stability of the euphotic zone. It seemed that the observed variations in $\mathrm{BP} / \mathrm{PP}$ ratios were due to the combined effects of turbulent mixing and water temperature on microbial food webs. Possibly, bacterial production and energy pathways in the Yellow Sea and other marine environments could be predicted by remotesensing of SST and ocean color.

Acknowledgements. We thank captain and crews of the RV 'Eardo', KORDI, for their excellent cooperation during the cruises. We thank 3 anonymous reviewers for helpful comments and Gabriela W. Smalley for improving the English. This work was in part supported by the Basic Science Research Institute Program, Ministry of Education, 1998, Project No. 1998-015-H00002, and by the BK 21 project of the Korean Government.

\section{LITERATURE CITED}

Agustí S, Satta MP, Mura MP, Benavent E (1998) Dissolved esterase activity as a tracer of phytoplankton lysis: evidence of high phytoplankton lysis rates in the northwestern Mediterranean. Limnol Oceanogr 43:1836-1849

Andersen P (1988) The quantitative importantance of the 'microbial loop' in the marine pelagic: a case study from the North Bering/Chukchi seas. Ergeb Limnol 31:243-251

Antoine D, Andre JM, Morel A (1996) Oceanic primary production. 2. Estimation at global scale from satellite (coastal zone color scanner) chlorophyll. Global Biogeochem Cycles 10:57-69

Azam F (1998) Microbial control of oceanic carbon flux: the plot thickens. Science 280:694-696

Azam F, Smith DC (1991) Bacterial influence on the variability in the ocean's biogeochemical state: a mechanistic view. In: Demers S (ed) Particle analysis in oceanography. Springer-Verlag, New York, p 213-236

Azam F, Fenchel T, Field JG, Gray JS, Meyer-Reil LA, Thingstad F (1983) The ecological role of water-column microbes in the sea. Mar Ecol Prog Ser 10:257-263

Baines SB, Pace ML (1991) The production of dissolved organic matter by phytoplankton and its importance to bacteria: patterns across marine and freshwater systems. Limnol Oceanogr 36:1078-1090

Berges JA, Falkowski PG (1998) Physiological stress and cell death in marine phytoplankton: induction of proteases in response to nitrogen or light limitation. Limnol Oceanogr 43:129-135

Biddanda B, Opsahl S, Benner R (1994) Plankton respiration and carbon flux through bacterioplankton on the Louisiana shelf. Limnol Oceanogr 39:1259-1275

Bronk DA, Glibert PM (1991) A ${ }^{15} \mathrm{~N}$ tracer method for the measurement of dissolved organic nitrogen release by phytoplankton. Mar Ecol Prog Ser 77:171-182

Cho BC, Choi JK, Chung CS, Hong GH (1994a) Uncoupling of bacteria and phytoplankton during a spring diatom bloom in the mouth of the Yellow Sea. Mar Ecol Prog Ser 115: 181-190

Cho BC, Kang YS, Choi JK (1994b) Spatial and temporal char- 
acteristics of distributions of bacteria in the mideast part of the Yellow Sea. J Korea Soc Oceanogr 29:145-151 (in Korean)

Choi JK (1991) The influence of the tidal front on primary productivity and distribution of phytoplankton in the mideastern coast of Yellow Sea. J Oceanol Soc Korea 26: 223-241 (in Korean)

Cole JJ, Findlay S, Pace ML (1988) Bacterial production in fresh and saltwater ecosystems: a cross-system overview. Mar Ecol Prog Ser 43:1-10

Conan P, Turley C, Stutt E, Pujo-Pay M, van Wambeke F (1999) Relationship between phytoplankton efficiency and the proportion of bacterial production to primary production in the Mediterranean Sea. Aquat Microb Ecol 17:131-144

Cushing DH (1989) A difference in structure between ecosystems in strongly stratified waters and in those that are only weakly stratified. J Plankton Res 11:1-13

del Giorgio PA, Cole JJ, Cimbleris A (1997) Respiration rates in bacteria exceed phytoplankton production in unproductive aquatic systems. Nature 385:148-151

Ducklow HW, Carlson CA (1992) Oceanic bacterial production. In: Marshall KC (ed) Advances in microbial ecology, Vol 12. Plenum Press, New York, p 113-181

Ducklow HW, Kirchman DL (1983) Bacterial dynamics and distribution during a spring bloom in the Hudson River plume, USA. J Plankton Res 5:333-355

Ducklow HW, Kirchman DL, Quinby HL (1992) Bacterioplankton cell growth and macromolecular synthesis in seawater cultures during the North Atlantic spring phytoplankton bloom, May, 1989. Microb Ecol 24:125-144

Dugdale RC, Wilkerson FP (1986) The use of ${ }^{15} \mathrm{~N}$ to measure nitrogen uptake in eutrophic oceans; experimental considerations. Limnol Oceanogr 31:673-689

Eppley RW (1972) Temperature and phytoplankton growth in the sea. Fish Bull 70:1063-1085

Eppley RW (1986) Plankton dynamics of the Southern California Bight. Springer-Verlag, New York

Eppley RW, Peterson BJ (1979) Particulate organic matter flux and planktonic new production in the deep ocean. Nature 279:210-215

Eppley RW, Sharp JH, Renger EH, Perry MJ, Harrison WG (1977) Nitrogen assimilation by phytoplankton and other microorganisms in the surface waters of the central North Pacific Ocean. Mar Biol 39:111-120

Falkowski PG, Woodhead AD (1992) Primary production and biogeochemical cycles in the sea. Plenum Press, New York

Fuhrman JA (1999) Marine viruses and their biogeochemical and ecological effects. Nature 399:541-548

Glibert PM, Goldman JC, Carpenter EJ (1982) Seasonal variations in the utilization of ammonium and nitrate by phytoplankton in Vineyard Sound, Massachusetts, USA. Mar Biol 70:237-249

Grasshoff K, Ehrhardt M, Kremling K (1983) Methods of seawater analysis, 2nd edn. Verlag Chemie, Weinheim

Griffith PC, Douglas DJ, Wainright SC (1990) Metabolic activity of size-fractionated microbial plankton in estuarine, nearshore, and continental shelf waters of Georgia. Mar Ecol Prog Ser 59:263-270

Hagström A, Azam F, Ansersson A, Wikner J, Rassoulzadegan F (1988) Microbial loop in an oligotrophic marine ecosystem: possible roles of cyanobacteria and nanoflagellates in the organic fluxes. Mar Ecol Prog Ser 49:171-178

Kiørboe T (1993) Turbulence, phytoplankton cell size, and the structure of pelagic food webs. In: Advances in marine biology, Vol 29. Academic Press, New York, p 1-72

Kiørboe T, Kaas H, Kruse B, Møhlenberg F, Tiselius P, Ertebjerg G (1990) The structure of the pelagic food web in rela- tion to water column structure in the Skagerrak. Mar Ecol Prog Ser 59:19-32

Kirchman DL, Hoch MP (1988) Bacterial production in the Delaware Bay estuary estimated from thymidine and leucine incorporation rates. Mar Ecol Prog Ser 45:169-178

Kirchman DL, Keil RG, Simon M, Welschmeyer NA (1993) Biomass and production of heterophic bacterioplankton in the oceanic subarctic Pacific. Deep-Sea Res 40:967-988

Kirchman DL, Rich JH, Barber RT (1995) Biomass and biomass production of heterotrophic bacteria along $140^{\circ} \mathrm{W}$ in the equatorial Pacific: effect of temperature on the microbial loop. Deep-Sea Res Part II Top Stud Oceanogr 42: 603-619

Koike I, Holm-Hansen O, Biggs DC (1986) Inorganic nitrogen metabolism by Antarctic phytoplankton with special reference to ammonium cycling. Mar Ecol Prog Ser 30:105-116

Legendre L, Gosselin M (1989) New production and export of organic matter to the deep ocean: consequences of some recent discoveries. Limnol Oceanogr 34:1374-1380

Legendre L, Le Fèvre J (1989) Hydrodynamic singularities as controls of recycled versus export production in oceans. In: Berger WH, Smetacek VS, Wefer G (eds) Productivity of the ocean: present and past. Wiley, Chichester, p 49-63

Legendre L, Le Fèvre J (1995) Microbial food webs and the export of biogenic carbon in oceans. Aquat Microb Ecol 9: $69-77$

Li WKW (1985) Photosynthetic response to temperature of marine phytoplankton along a latitudinal gradient $\left(16^{\circ} \mathrm{N}\right.$ to $\left.74^{\circ} \mathrm{N}\right)$. Deep-Sea Res 32:1381-1391

McManus GB, Peterson WT (1988) Bacterioplankton production in the nearshore zone during upwelling off central Chile. Mar Ecol Prog Ser 43:11-17

Moran MA, Wicks RJ, Hodson RE (1991) Export of dissolved organic matter from a mangrove swamp ecosystem: evidence from natural fluorescence, dissolved lignin phenols, and bacterial secondary production. Mar Ecol Prog Ser 76: 175-184

Nagata T (1986) Carbon and nitrogen content of natural planktonic bacteria. Appl Environ Microbiol 52:28-32

Owens NJP (1988) Rapid and total automation of shipboard ${ }^{15} \mathrm{~N}$ analysis: examples from the North Sea. J Exp Mar Biol Ecol 122:163-171

Paasche E, Kristiansen S (1982) Nitrogen nutrition of the phytoplankton in the Oslofjord. Estuar Coast Shelf Sci 14: 237-249

Parsons TR, Maita Y, Lalli CM (1984) A manual of chemical and biological methods for seawater analysis. Pergamon Press, Oxford

Peters F, Marrasé C, Gasol JM, Sala MM, Arin L (1998) Effects of turbulence on bacterial growth mediated through food web interactions. Mar Ecol Prog Ser 172:293-303

Petersen JE, Sanford LP, Kemp WM (1998) Coastal plankton responses to turbulent mixing in experimental ecosystems. Mar Ecol Prog Ser 171:23-41

Platt T, Sathyendranath S (1988) Oceanic primary production: estimation by remote sensing at local and regional scales. Science 241:1613-1620

Porter KG, Feig YS (1980) The use of DAPI for identifying and counting aquatic microflora. Limnol Oceanogr 25:943-948

Prabhakara C, Dalu G, Kunde VG (1974) Estimation of sea surface temperature from remote sensing in the 11- to 13- $\mathrm{um}$ window region. J Geophys Res 79:5039-5044

Probyn TA (1985) Nitrogen uptake by size-fractionated phytoplankton populations in the southern Benguela upwelling system. Mar Ecol Prog Ser 22:249-258

Probyn TA, Waldron HN, James AG (1990) Size-fractionated measurements of nitrogen uptake in aged upwelled waters: 
implications for pelagic food webs. Limnol Oceanogr 35: 202-210

Raven JA, Geider RJ (1988) Temperature and algal growth. New Phytol 110:441-461

Robinson C, Williams PJleB (1993) Temperature and Antarctic plankton community respiration. J Plankton Res 15 1035-1051

Sanford E (1999) Regulation of keystone predation by small changes in ocean temperature. Science 283:2095-2097

Shim JH, Park MG, Yang SR, Cho BC (1996) Nitrogen dynamics during the early phase of tidal front formation in the mid-eastern part of the Yellow Sea. The Yellow Sea 2: $15-25$

Simon M, Azam F (1989) Protein content and protein synthesis rates of planktonic marine bacteria. Mar Ecol Prog Ser 51:201-213

Smith D, Simon M, Alldredge AL, Azam F (1992) Intense hydrolytic enzyme activity on marine aggregates and implications for rapid particle dissolution. Nature 359:139-142

Editorial responsibility: Otto Kinne (Editor), Oldendorf/Luhe, Germany
Smith D, Steward GF, Long RA, Azam F (1995) Bacterial mediation of carbon fluxed during a diatom bloom in a mesocosm. Deep-Sea Res II 42:75-98

Smith KL Jr, Kaufmann RS (1999) Long-term discrepancy between food supply and demand in the deep eastern North Pacific. Science 284:1174-1177

Smith WO Jr, Harrison WG (1991) New production in polar regions: the role of environmental controls. Deep-Sea Res 38:1463-1479

SPSS Inc. (1997) SPSS for Windows. SPSS Inc, Chicago, IL

Taylor AH, Joint I (1990) A steady-state analysis of the 'microbial loop' in stratified systems. Mar Ecol Prog Ser 59: $1-17$

White PA, Kalff J, Rasnussen JB, Gasol JM (1991) The effect of temperature and algal biomass on bacterial production and specific growth rate in freshwater and marine habitats. Microb Ecol 21:99-118

Williams N (1998) The Mediterranean beckons to Europe's oceanographers. Science 279:483-484

Submitted: April 27, 2000: Accepted: December 15, 2000

Proofs received from author(s): June 25, 2001 